\title{
The Curriculum as Cultures in Conflict: Exploring Monocultural and Multicultural Ideologies through the Case of Bilingual Education
}

\author{
Juanjuan Zhu \\ Steven P. Camicia
}

\begin{abstract}
Curriculum contentions are cultural struggles. As an illustration, we examine contention surrounding which and how languages are taught in the curriculum. We (the authors) locate this struggle within our positionalities, as a departure for our analysis of competing ideologies surrounding language and curriculum. We use a dialogical methodology to examine tensions between monocultural and multicultural ideologies. An imaginary dialogue between us, Hirsch, and Bakhtin provides an illustration. Based upon the struggles located in the bodies of the authors and the imaginary dialogue of two cultural theorists, we conclude that a monological curriculum represents the domination of one cultural group over others rather than the pedagogical and social rationales provided by opponents of multilingual education.
\end{abstract}

\section{Introduction}

Ideological struggles find their way into the public school curriculum because the curriculum contains assumptions about what knowledge society judges as "legitimate", "good", "true", "neutral", and "official” (Apple, 2000). These struggles emerge from normative sociocultural disputes over ideologies concerning, for example, family (Turner-Vorbeck, 2006), community (Katriel \& Nesher, 1986), race (Banks, 2002), gender (Baxter, 2002), and history (Evans, 2004; Wertsch, 2002). Contention surrounding curriculum in general (Kliebard, 2004; Zimmerman, 2002), and the inclusion of languages other than English in particular, have been a source of continuous cultural tension in the United States (Crawford, 2000b; Demas \& Saavedra, 2004; Gann, Dean, \& Márquez, 2005; Stritikus, 2002).

In this article, we use the dominance of English as a case to show how curriculum struggles reflect larger contentions within society. We examine competing ideologies concerning the inclusion of languages other than English in the curriculum of America's public schools. Aligned with the topic at hand, we have chosen a dialogical method to illustrate these tensions. We construct an imaginary dialogue between two different ideologies, with E. D. Hirsch representing a monolingual ideology and Mikhael Bakhtin representing a multilingual ideology. Our goal is not to present a definitive dialogue about the struggle over language but 
to tease out some of the different ideological forces at work in curriculum struggle writ broadly.

We begin by presenting the tension that exists between the positionalities of us as the authors. This tension locates our involvement with this article as a site of political struggle similar to the kinds of struggles that happen in curriculum disputes, and as a result, curriculum reform. As authors, we embody this struggle through our different lived experiences and complex mix of identities. We maintain that curriculum struggles, such as those over language, are fueled by contact between individuals and groups that are inscribed by different identities.

This said, the following question might be asked: Why are we, the authors, comparing two men? We present these two White men (Hirsch and Bakhtin) because while they embody many of the same identities, they present another level of complexity to the ideology mix. We define ideology as a system of thoughts, perceptions, interpretations, and discourses. Ideologies often cut across the embodiment of different identities. I, Juanjuan, am a Chinese female, and I, Steven, am a White American male. We present an imaginary dialogue between Hirsch, Bakhtin and us, the two authors, in order to illustrate this complexity between identity and ideology. We conclude by extending the dialogue toward a new understanding of language, culture, and conflict within the public school curriculum. We use the duoethnography method (Lund \& Navabi, 2008; Norris, 2008) as a guideline in our examination because duoethnography focuses upon the dialogical and contextual nature of understanding. In addition, duoethnography emphasizes the positionality of the researchers and the participants by making a link between perspectives and the unique identities and histories that they include. Rather than view positionality as a weakness or bias, the researchers embrace it as a way to show how their identities and histories inform investigation.

\section{Juanjuan's Positionality}

As an English language learner (ELL), I majored in English literature in college and devoted another two and half years to pursuing my Master's degree in Applied Linguistics in China. Immediately after graduation, I was offered a position as an EFL teacher at a college in Shanghai, China. Dissatisfied with China's foreign language education over the years while I was teaching, I came to the US for a better solution to the needs of my country, as well as a better education for myself. Unfortunately, I found that bilingual education in the US was also mired in difficulties, disputes, and contention. Much to my surprise, I found myself thinking that the country with the reputation for being the most diversified and internationalized in the world has been very parochial, egocentric, and malnourished linguistically (Simon, 1980; Panetta, 1999). Like many ELLs in this country, I sense displacement and dispossession keenly within a context where English is viewed as the only standard and valued language. Instead of being valued, as is the experience of many who speak languages other than English, my language serves to disgrace and degrade me, pushing me toward the margins of society. 
In classrooms, we ELLs are silenced and neglected when teachers and our classmates are using and can only use their Standard English to joke, chatter or protest. In schools, we are judged academically capable or not depending on how well we understand/speak/write English. In social situations, we are forced to follow the rules set by the Standard-English-speaking authorities and are rendered less opportunity to be engaged. For example, I have been constantly denied opportunities to work voluntarily as a teacher's assistant and tutor, as school authorities wanted native speakers. In this anguish, I asked Steven to join me in an effort to deconstruct monolingual language ideology and policy. My lived experiences and positionality encourage me to challenge the underpinnings of structuralists' perspectives toward language, transform relevant oppressive educational practices, and resist "the hegemony of English" (Demont-Heinrich, 2007) prevalent in this country and the world. In many ways, my body is a battleground for many of the curriculum struggles in the United States, a battle that I did not expect before I came here.

\section{Steven's Positionality}

As a White male who speaks only English, my positionality is privileged by the dominant culture of the United States. This privilege is reified through everything from textbooks to the unearned advantages given to me throughout my life. In addition to growing up in the San Francisco Bay area, I lived in Hong Kong during high school. Although there were many contexts within these communities where English was not the most widely spoken language, it was still the dominant one. This dominance was maintained through an intricate network of social structures such as curriculum, culture, and capital. It is within these structures that virtually all my identities were located upon the top of a hierarchy of oppression. In addition to my identity as a White male, my family was upper middle class. My ability to move seamlessly across borders added to my privilege, because not only was I able to escape oppression directed at "other" identity markers such as language, race, class, and gender, but I was also able to cross the bounds of geopolitical borders, what Ong (1999) terms as a "flexible citizen." In many ways, my body serves as a wall to those bodies, such as Juanjuan's, that are inscribed by identities different from the dominant culture.

In sum, our positionalities serve as an embodiment of the tension that we describe in the following imaginary dialogue. The dialogue illustrates a battle of ideologies found in many curriculum battles, but that is only part of the story. The other part of the story is the material reality of the bodies in which those battles occur. In the United States, these bodies are often those of ELL students. I, Juanjuan, stand on the margin looking in on a dominant culture that has little regard for my language and culture. I, Steven, stand in the center as an embodiment of the mainstream culture. It is within this tension that we hope to work together against the hegemony of the monocultural ideology that dominates many curriculum battles and much of the discussion surrounding bilingual education. 


\section{Bilingual Education in the US}

Before the imaginary dialogue on the US's bilingual education is presented, it would be helpful to have a quick overview of the background and context of this issue. According to Crawford (2000b) and Donegan (1996), bilingual and even multilingual education can be termed an early American tradition and norm. Before the $20^{\text {th }}$ century, bilingual public and vernacular private schools were commonly seen throughout the US as "a product of practical necessity or local choice" (Crawford, 2000 b, p. 100). This was due to efforts made in local schools to support the requests of immigrant parents and the lack of fully English-proficient teachers in large expanses of the country. Besides the most extensive German-English programs, French-language schools could be found in the Northeast, and Dutch-language schools in the middle states (Donegan, 1996).

However, at the beginning of the $20^{\text {th }}$ century, with the arrival of vast numbers of Southern and Eastern European immigrants in the US, certain state and federal laws were passed that restricted immigration and banned the teaching of foreign languages, especially German to schoolchildren. Then, "from World War I through the early 1950s, bilingual education lay dormant while a number of states passed laws forbidding the use of languages other than English at school" (Donegan, 1996, p. 62).

Since the 1960s, the rise of bilingual education in its modern form has caught wide attention and ignited ongoing debates (Bilingual Education Essays and Articles, 2011). This time, bilingual education was envisioned as a way to meet the needs of "the invisible minority" of Spanish-speaking children (National Education Association, 1966) and help reduce the high dropout rate among this group. One landmark event was the passage of Title VII of the Elementary and Secondary Education Act, also called the Bilingual Education Act, in Congress in1968. Born out of the civil rights movement and specifically rooted in the Civil Rights Act of 1964, the Bilingual Education Act sought to improve educational opportunities for language-minority children by providing federal funding to schools that serve children with limited English-speaking ability. Six years later, the US Supreme Court ruled in Lau v. Nichols that under the Civil Rights Act, LEP students have the right to special instructional materials in learning English. In the same year of 1974, Congress passed legislation that "required native-language instruction for nonEnglish-speaking students in school districts that applied for federal bilingualeducation grants" (Donegan, 1996, p. 62-63).

However, federal and state mandates for bilingual education soon provoked an antibilingual backlash. Starting from the early 1980s, national sentiment towards bilingual education began to shift, with critics questioning the effectiveness of such programs. Some opponents complained that too many children stayed too long with their mother tongue and "have failed to become fluent in English" (Bennett, 1985, as cited in Donegan, 1996, p. 59), while others cited the persistently high failure and dropout rate among Hispanic children after many years of bilingual education 
implementation (Crawford, 2000b). It is in reaction to these problems that a series of English-only laws came about. In 1983, US ENGLISH was founded by Sen. Hayakawa, R-Calif., as an organization promoting the legislation of English as the official language of the US. Three years later, a majority of California voters approved Proposition 63, declaring English as the state's official language. Disregarding professional advice from the field, in 1998 Californians also voted against bilingual education. Proposition 227 was passed; its aim was to drastically limit bilingual education in public schools in the state. Californians were definitely not alone in their opposition to bilingual education. Following suit, states like Arizona and Massachusetts approved similar initiatives against bilingual education in the early 2000s. Moreover, by now, 31 states have enacted official English laws (US ENGLISH, 2011), with various bills introduced in Congress to make English the official US language or to abolish government-mandated bilingual education on the national level.

To sum up, the past 50 years or so have witnessed a fierce competition between advocates and critics of bilingual education in the US. No final word has been made on the subject, as both the pro-bilingual-education camp and the proEnglish camp have drawn a considerable amount of money and support. With conservative forces gaining ground and restraints on bilingual education gaining momentum in the most recent years, the debate may become more intense. The following dialogue seeks to add complexity to the debate.

\section{An Imaginary Dialogue between Competing Ideologies}

At noon on a chilly October day in Logan, Utah, the Bluebird Cafe was unusually warm and illuminated by the presence of intellectuals whose ideas have greatly shaped and/or challenged the educational picture of this century and beyond. They were at the cafe to take an intermission from the Centennial International Education Forum, where we were voluntary interpreters for Mikhail Mikhailovich Bakhtin, a Russian philosopher and advocate for "heteroglossia and dialogic intertexuality" (Ball \& Freedman, 2004) and Eric Donald Hirsch, Jr., an American conservative scholar concerned with school curricula (Schultz, 2001, p. 13). They began to speak about bilingual education in the US:

Hirsch: Welcome, Mr. Bakhtin. How have you enjoyed your stay at Logan? Have you had a chance to visit the beautiful canyons or meet the people?

Bakhtin: The people are very friendly and the landscape is incredible. I love talking with the young people because they have such enthusiasm and great ideas. The only pity is that so far I haven't met anyone who can communicate with me well in Russian. Is it still common for people like me who speak a language other than English to encounter this problem in the US?

Hirsch: Very much so, especially when the people who speak the same language as you don't constitute a large portion of the US population. Monolingualism is, by and large, taken as an "unsullied essence" (Moraes, 1996, p.43). 
Juanjuan: Sorry to interrupt, but I need to add that it's also my experience here. As a speaker of Mandarin Chinese, the language spoken by the largest population in the world, I could hardly make any use of it after I arrived in the US, except with my native friends. Luckily, given my age, my Chinese hasn't eroded much. But I'm in total sympathy with immigrant children here and all over the world because I have experienced their sufferings to a great extent.

Steven: Having grown up in the United States, I have never had to learn any language except for English. I value friends and colleagues such as Juanjuan who help me understand what it might be like to live in a country where something as important as my first language is not valued, at best, and seen as a deficit, at worst.

Bakhtin: Interesting. What all of you said reminds me of the heated debate on bilingual education worldwide. Perhaps the US has experienced-and will continue to experience-one of the fiercest quarrels over this issue. In my mind, it illustrates how struggles over language are power struggles over culture.

Steven: Yes. As part of the dominant culture in the United States, I have seen this struggle through the discourses surrounding bilingual education and immigration policy. While opponents of bilingual education support their position through claims for the "common good," I see these as veiling the true issue, which is "protecting" the position of the dominant culture in the curriculum.

Hirsch: Speaking of that, I have some strong opinions against the progressive's vision of bilingual education and culture. You, Mr. Bakhtin, also have a strong vision of language, literacy, learning, curriculum, and culture. If you don't mind, why don't we talk a bit about bilingual education to see if we can work out a better solution for everyone? It seems like the perfect issue in curriculum contention to understand how curriculum is integral to culture. While I am sympathetic to Juanjuan and other marginalized students, what I propose will be good for them and the country. While I value Juanjuan's first language, I think that she is better served by immersion into the dominant language in this country, because English "is the ticket to the American dream" (Dole, 1995, as cited in Donegan, 1996, p. 51).

Bakhtin: Before we start, we need to define bilingual education.

Hirsch: Maybe we can use this one. (Opening his computer and searching online for National Association of Bilingual Education[NABE]) Let's see. Eh, right here on the NABE website:

What Is Bilingual Education? [...] Defined broadly, it can mean any use of two languages in school-by teachers or students or both-for a variety of social and pedagogical purposes. In today's context, a period of demographic transformation in United States [sic], bilingual education means something more specific. It refers to approaches in 
the classroom that use the native languages of English language learners (ELLs) for instruction. (NABE, 2008)

However, I don't agree with this. (Clicking on another webpage) The Wikipedia website states, "Effective bilingual programs strive to achieve proficiency in both English and the students' home language" (Bilingual Education, n. d.). It's a progressive view. I believe that a student's native language should be abandoned after students are transitioned entirely to the official standard language of English (Saville-Troike, 2006, p. 129). We used to name ELLs as LEP (limited English proficiency) students (August \& Hakuta, 1997). This placed an emphasis upon English as the dominant language. A strong nation must have a unified and dominant language and culture. Otherwise, a big and multiethnic nation like the US will be separated "into warring ethnic camps", with people "confined to language ghettos, isolated from economic opportunity and contemptuous of US culture" (Donegan, 1996, p. 52).

Juanjuan: With due respect, I have always seen such claims for "unity" and "dominance" as a convenient excuse for the marginalization and oppression of certain minority groups, in this case, language minorities. Such a practice cannot help build a strong nation. If you have studied Chinese history, you will find abundant examples where dominance only led to resistance, rebellion, and the demise of a dynasty. Instead, prosperity existed when diverse languages, cultures, and voices were valued in the nation. Ironically, such crucial knowledge embraced by language minority groups is exactly what has been disregarded in the mainstream culture of America.

Bakhtin: Courtney Cazden and Catherine Snow (as cited in Moraes, 1996, p. 41) once commented that "Bilingual education' is a seemingly simple label for a complex phenomenon." This is due to the influence of power on the struggle over language in the curriculum, a struggle of competing cultures and ideologies. There can be no question that ELLs are placed in "predetermined positions of powerlessness" (Moraes, 1996, p. 66). This is only strengthened by the mainstream preference for a unified language and culture.

Steven: As a White male, I grew up with this conception of a "unified language and culture." I am amazed that it wasn't until my 20's that I began to question why such concepts of unification exist. My entire education, from history to language arts, was bolstered by this assumption. I can't help but wonder how much richer the world would have seemed had I been taught to embrace difference as a strength rather than a weakness.

Bakhtin: You, Mr. Hirsch, construct a dichotomy between ELLs and native English speakers. This is illustrated by the label "LEP." The implication is that English is the only official or valued language in the US. In fact, many states have English-only laws (English-Only Movement, n. d.). The movement toward English-only has boomed as the population of English-language learners increases. According to the National Center for Education Statistics (2009), 
"between 1979 and 2007, the number of school-age children (children ages 5-17) who spoke a language other than English at home increased from 3.8 to 10.8 million, or from 9 to 20 percent of the population in this age range." When we deny students the opportunity to include their languages in the curriculum, we deny their voice, their real selves and their culture. I can't help but think that this is an attempt by one culture to use language as a way to dominate another culture (Reagan \& Osborn, 2002). And such ideology well explains why living, and schooling in particular, in English-only America could be a painful experience for students like Juanjuan and numerous immigrant families (Kouritzin, 2000; Wong Fillmore, 1991).

Hirsch: So you think the bilingual education policy in the US should not only be addressed to ELLs, but to all Americans, allowing equal treatment and encouraging learning of multiple languages?

Bakhtin: You are getting close, but to really appreciate my vision, you first need to tell me more about your understanding of language.

Hirsch: Well, I'm not a linguist. But I'm for Saussure's conception of language, which has shaped our traditional linguistics. He is a structuralist because he interprets language as a homogenously used abstract semiotic system, which "must be studied in itself" (1959, p. 16). His view was extended by Noam Chomsky, whose hypothesis of Universal Grammar has gained wide recognition. They both believe in the existence of a unitary standard language. And as language is objective, it can be analyzed outside of the context in which it is used, a context involving differences in power and people.

Bakhtin: According to my understanding, language is "a semiotic social-cultural entity that is dialogically alive and mutable" (Moraes, 1996, p. 91). Let me explain. First of all, every word becomes a meaningful embodiment of ideologies and cultures when used in human communication (Moraes, 1996, p. 92). During the dialogical exchange of consciousness between the speaker and the listener, language exists and can only be understood through social, cultural, and historical contexts. Given that language is a living and changing thing, or in Moraes' words, "a dynamic social entity and a socio-cultural phenomenon" (1996, p. 92), we cannot analyze it outside of social relations. Therefore, language education should not be restricted to a study of language; rather, it should be extended to attain a comprehensive, historical knowledge of the culture encompassed in that language. Bilingual education is and should be bicultural education, or even multicultural education on account of the in-use plurality of life experience, a plurality that should be encouraged to thrive in the US. Language minority groups should not be discriminated against because of their native language. Instead, individuals like Juanjuan should be valued and respected for bringing different social, cultural, and historical perspectives into the US so that everyone can better understand themselves and the world and thus embrace democracy in a more universal sense. 
Hirsch: You might be right there. But what I'm concerned about is that language freedom might ferment separatism and fragmentation by maintaining immigrants' ties with their old country, posing a threat to American civilization and the unity and solidity of America as one powerful democratic nation. Clearly, I am not the only person who is bothered by this thought. As early as 1787, one of our founding fathers, Thomas Jefferson, had warned that European immigrants would transmit with their language antidemocratic principles to their children. More than two centuries later, Newt Gingrich (1995), a politician of our time, commented in his book To Renew America that

Bilingualism keeps people actively tied to their old language and habits and maximizes the cost of the transition to becoming American. As a result, poor Americans and first-generation immigrant children have suffered pain and confusion[...] The only viable alternative for the American underclass is American civilization[...] Without English as a common language, there is no [American] civilization. (p. 162)

Therefore, bilingual education with the ultimate goal of helping immigrant children become fluent in the dominant language of English, not their native language, would "halt the 'tribalization' of US culture, diminish separatism, reinforce the shared values of a common culture" (Donegan, 1996, p. 58) and keep the democracy of America intact.

Bakhtin: I can't agree with that. Quite to the contrary, anyone who's championing English-only is actually exerting "a form of ethnic suppression" (Moraes, 1996, p. 62). Just as Peter McLaren argued, the conservative notion of nationalism would produce citizens "who are committed to entrepreneurship, who will fight to keep English the official language of the country[...] who will cherish and defend neocolonial imperatives of a new world order ruled by the United States" (Steinberg, 1992, p. 403). Taking it a step further, Thomas (1996), in his critical analysis of the agenda of US ENGLISH, concluded that "history indicates that restricting language rights can be divisive and can lead to segregationist tendencies in a society. At the same time, such legislation rarely results in a unified society speaking solely the mandated language(s)" (p. 129). Arturo Madrid (1990) summarized what I believe: For any nation, "far more important as forces to get itself unified were individual rights, freedoms, and protections; governmental and societal tolerance for cultural, linguistic, and religious diversity; democratic representation; and unfettered commerce" (p. 63).

Hirsch: You make some good points, but your philosophy is easier said than done. Your vision of bilingual education is not that feasible. In contrast, my vision is more down-to-earth. In fact, the past decades have witnessed the large-scale implementation of several bilingual instructional programs with, in Lambert's (1974) taxonomy, a subtractive outcome (as cited in Saville- 
Troike, 2006, p. 127). Transitional Bilingual Education (TBE) is a prime example, as it aims at "fluency in English without considering bilingualism as necessary" (Moraes, 1996, p. 43).

Bakhtin: But its effectiveness has been under severe criticism. Being applied widely is no argument for its use. In fact, educators sharing my vision of bilingual schooling have been innovative enough to revolutionize, first of all, teaching methodologies. We challenge the "student-as-worker, teacher-as-coach" concept advocated by your ally Theodore Sizer in his nine common principles, and the didactic approach backed by Mortimer Adler (1982), another companion of yours. This teaching model not only bores students but perpetuates education as a reproductive process that maintains existing inequalities and hegemony.

Hirsch: But we should maintain teachers' authority in front of students when dispensing knowledge. In the pedagogical relations, teachers are naturally in a more authoritative and higher position than students. Teachers earn this position because they tend to be more mature in character, more experienced in problem solving, and more knowledgeable in at least the content area(s) they teach than their students. Therefore teachers should be given the power to transfer knowledge to students through, say, lecturing and drilling, choose the program contents as they see appropriate for students' developmental levels, and discipline students to maintain an orderly learning environment. Students, on the other hand, should listen and strictly follow directions from teachers, adapt to the contents as prescribed, and comply with established disciplines (Freire, 2000). Especially when it comes to language education, teachers should be treated as indisputable authorities with absolute respect because they are usually the native speakers. They aid in their immigrant students' acquisition of Standard English by filling the latter with crucial linguistic and cultural knowledge, and setting up an authentic model for the latter to imitate.

Bakhtin: What you are describing is Freire's $(1998,2000)$ notion of the banking system of education where teachers deposit and withdraw knowledge from the minds of students. As far as language education is concerned, a monologic or standardized form of language is encouraged in your model. The teacher and society are in the position to judge "which languages are appropriate and which must be marginalized" (Moraes, 1996, p. 95) thus positioning students into hierarchical relationships in their classrooms and society.

Hirsch: Then what would you propose instead?

Bakhtin: I suggest a dialogical approach, which might be close to Freire's theory of a dialogic pedagogy (Moraes, 1996, pp. 103-104). I agree with Denzin (2009), who writes, "Critical pedagogy is a dialectical and dialogical process. Revolutionary, radical (and reflexive) performance pedagogy critically situates agency, identity, and discourse within and against a broader historical landscape" (p. 382). In the dialogue, two parts are coexistent: "the 
self and the other;" and "the other cannot be silenced and excluded" (Moraes, 1996, p. 94). We must interrogate the way that dominant culture uses language to sustain and strengthen hierarchies of oppression. Therefore, when it comes to teacher-student relations, they are both equal entities in the educational practices and they both "become agents in a struggle for social and political transformation" (Moraes, 1996, p. 111). In the case of language education, teachers should appreciate "multivoicedness" (Moraes, 1996, p. 126), or what students from diverse backgrounds bring into their classrooms. They should learn with all students by including a dialogue based upon one another's cultures and experiences. My educational vision is transformative because it cultivates responsible citizens and critical thinkers.

Hirsch: Could such a relation be kept the same when evaluation is involved in your model? To be frank, I really doubt it, because educators need standards to ensure objectivity. Here I have to resort to Saussure and Chomsky again as their philosophy of language enables us to measure student success with well-defined parameters such as grammatical mistakes. When we interpret language as a uniform, homogenously used abstract system, it naturally follows that language competence can be assessed through a set of standardized tests, which present an objective reflection of the learners' factual mastery of all linguistic components, such as grammar, vocabulary, listening and writing skills. Moreover, the errors made by language learners should be quantifiable and identifiable so that students can have a clear idea as to what their weaknesses are and how far away they are from acquiring the standard language.

Bakhtin: That is exactly the point I want to counter. Yes, we do need some standards to make judgments accordingly. However, standards blind us to the fact that we are using them only for the sake of convenience, and they perpetuate structures of dominance and subjugation (Fulcher \& Davidson, 2008). When assessed, students are no longer lively beings unique in certain aspects; rather, they are reduced to a combination of lifeless numbers. If I were an evaluator in a language program, I would not use tests that isolate different aspects of language acquisition like reading, listening, or focusing on grammar only, or fabricating fictional situations for speaking. I would, instead, examine students in different discourses and contexts, trying to seek as wide a variety of information as possible. I also prefer to focus upon personal growth. I prefer to cherish their language profile, "living trace" (Dressman, 2004, p. 35) and culture stock (Delpit, 1995) as a way to understand their educational needs. These needs are never static. They change just as language changes. Words such as less intelligent or less competent are not in my lexicon, especially when non-native-speakers are concerned.

Juanjuan (exclaiming): I like this idea! This way students like me could be relieved of the constant pressure to be judged upon our grasp of meticulous language points. 
Steven: I agree. In addition to being a more just and compassionate approach to educating non-English-speaking students, this approach provides a context for students like me from the dominant culture to understand the perspectives of student who speak little or no English. This is the first step away from discourses that portray non-English speakers as having a deficit.

Hirsch: But you have neglected the fact that objective results obtained in evaluation would be instrumental in helping us carry out research more easily and persuasively to direct our curriculum decisions. The fact that we are having this debate here is largely because the past studies in this field only present indefinite findings (Bilingual Education Essays and Articles, 2011; Donegan, 1996) and divisive opinions (e.g., Kouritzin, 2000; Samimy, 2001). Therefore, I hold that more research should be conducted objectively so as to inform us of the correct way of implementing bilingual education.

Bakhtin: Talking about research, we are now approaching the third aspect of language education. Given the fact that our ideologies are discordant in the first two aspects, namely, teaching methodology and assessment, I have every reason to believe we would also differ considerably in this aspect as well.

Hirsch: It seems that under the influence of Saussure and, in particular, Chomsky, linguists favor the cognitive-computational tradition, as Johnson (2004) mentioned in her overview of three major SLA research traditions. Quantitative methods are employed to prove man's homogeneity based on the assumption that processes of language production are rule-governed (Johnson, 2004, pp. 11-16). Moreover, researchers involved in this tradition tend to hold a positivistic epistemology and believe "there is a single tangible reality 'out there'" (Lincoln \& Guba, 1985, p. 37). It is the strongest tradition so far and widely conducted by the mainstream SLA community (Johnson, 2004, p. 15).

Bakhtin: Exactly. But please forgive me for my boldness in saying that it makes me see the weakness of your theory more clearly. First of all, the tradition runs the risk of "overgeneralization" (Moraes, 1996, p. 88) because it fails to study language in ever-changing sociocultural and historical contexts. Secondly, as Nunan (1991) noted, "little second language research is actually carried out in language classrooms, and [...] we know comparatively little about what does or does not go on there" (p. 265). That is to say, what is overlooked in standard research is the fact that "the dimension of the development in any process of learning cannot be just measured on the basis of tests" (Moraes, 1996, p. 88). Therefore, what I'm constructing is a qualitative approach or longitudinal case study, if possible. Understanding that language is a medium for social life (Halliday \& Hasan, 1985), I believe "there are multiply constructed realities" (Lincoln \& Guba, 1985, p. 37) to explain personal encounters. Besides that, the dialogical research following my vision allows language studies done in real contexts and results applied to real contexts. As such, I'd like to quote the metaphor that Voloshinov (1973), my close friend 
who specializes in linguistics, made once to elucidate my point: "in order to observe the process of combustion, a substance must be placed into the air. In order to observe the phenomenon of language, both the producer and the receiver of sound and the sound itself must be placed into the social atmosphere" (as cited in Moraes, 1996, p. 88).

Mr. Bakhtin is about to say more, but Mr. Hirsch glances at his watch, suggesting it's time for us to leave. Reluctant to depart, we are full of gratitude to both of the gentleman for allowing us to interpret for and converse a bit with them. Mr. Bakhtin, sharp as usual, asks about our final thoughts before we go.

\section{Conclusion}

We conclude by saying: Mr. Hirsch, please forgive us for saying that social life is embedded within dynamic and complex sociocultural contexts. Hierarchies of oppression are an integral part of these contexts and your vision seeks to reinscribe these hierarchies on the bodies of new generations of children by placing English at the top of the hierarchy of identities. This has served to privilege some, such as me, Steven, and oppress others, like me, Juanjuan. We embody the struggle which your ideological dialogue with Mr. Bakhtin represents. While neither of us asks for privilege or oppression, it is something that is cast on us by society and perpetuated with policies such as English-only laws in public schools.

Dressman (2004) once described the two aspects of pedagogy of literature, namely, instruction and curriculum, as forming a two-dimensional world. However, your ideological disputes over language education today reveal a slightly different, but more detailed, vivid, three-dimensional plane for us (See Figure 1 in Appendix). It seems that you two are dwelling in the two opposite spaces, with Mr. Hirsch and his monolingualism occupying the northeast quadrant of the figure and with $\mathrm{Mr}$. Bakhtin and his multilingualism occupying the southwest quadrant. To be specific, along the horizontal, or instructional method, axis, you place yourselves at the two ends of a continuum, championing the banking/monological approach and dialogical approach respectively. Along the vertical, or assessment, axis, you locate yourselves at the two ends of another continuum, one advocating a single dominant epistemology and the other advocating multiple epistemologies. Concerning the last axis of research paradigm, Mr. Hirsch represents a post-positivist perspective while Mr. Bakhtin represents a critical perspective.

We, Juanjuan and Steven, agree with Mr. Bakhtin, especially where critical issues determining our future development are concerned. Given that this country's demographic texture is changing every day and globalization is speeding up ever faster (Held, McGrew, Goldblatt, \& Perraton, 1999), bilingual education is at the top of our concerns. To defend our ideal of democracy from the attack of market rationality, we should cultivate bilingual or even multilingual people who embrace knowledge about cultures other than their own. They are the ones who generously share their legacy with other nations and are open-minded enough to appreciate truth and beauty from other parts of the world. Most importantly, they are the ones who never get tired of striving for an equal, democratic, non-hierarchical and 
peaceful coexistence of all human beings. In this regard, we believe Mr. Bakhtin's poststructuralism could better cater to contemporary demands, because critical thinking and deconstruction are at the heart of dismantling hierarchies that privilege dominant cultures and perspectives.

In this article, we, Juanjuan and Steven, have taken steps toward dismantling hierarchies embedded in issues such as bilingual education. We hope that our dialogical perspective will promote other dialogues surrounding curriculum struggles in the schools. The conflicts in such struggles are productively examined through the lens of cultural conflict. In addition to language education, this dialogue can occur in other curriculum struggles such as mathematics, social studies, and science. We propose starting these dialogues by asking questions such as: What culture has most defined success? And how does the curriculum position students within hierarchies of oppression? We, Juanjuan and Steven, have experienced the effects of curriculum in their material, psychological, and spiritual repercussions in our lives. Thus, we hope to alleviate the suffering of unjust repercussions in future generations of students through the dialogue we open up in this article.

We chose to use a method similar to duoethnography by presenting different positionalities within a dialogue. The challenge of this method is that it encourages a multivocal text. Because standard or dominant academic discourse privileges collapsing different perspectives into one, it can be difficult to break away from that model in favor of a multivocal text or examination. This can also lead to a multiplication of complexity because issues are examined from multiple perspectives. Finally, we believe that explicit dialogue around positionality and controversial issues is an important part of moving toward the empowerment of marginalized voices. This dialogic approach can provide the space for multiple perspectives to emerge that are normally silenced within a movement toward dominant positionalities and perspectives.

\section{References}

Adler, M. (1982, July). The Paideia proposal: Rediscovering the essence of education. In F. Schultz (Ed.), Notable selections in education (3 ${ }^{\text {rd }}$ ed., pp. 32-38). Guilford, CT: McGraw-Hill/Dushkin.

Apple, M. W. (2000). Official knowledge: Democratic education in a conservative age (2nd ed.). New York: Routledge.

August, D., \& Hakuta, K. (Eds.). (1997). Improving schooling for language-minority children. Retrieved from http://books.nap.edu/openbook.php?record id=5286\&page $=2$

Ball, A. F., \& Freedman, S. W. (Eds.). (2004). Bakhtinian perspectives on language, literacy, and learning. Cambridge, MA: Cambridge University Press.

Banks, J. A. (2002). Race, knowledge construction, and education in the USA: Lessons from history. Race, Ethnicity, and Education, 5(1), 7-27. 
Baxter, J. (2002). Competing discourses in the classroom: A post-structuralist discourse analysis of girls' and boys' speech in public contexts. Discourse and Society, 13(6), 827-842.

Bilingual education. (n. d.). Retrieved from http://en.wikipedia.org/wiki/Bilingual education\#United States

Bilingual Education Essays and Articles. (2011). Retrieved from http://www.enotes.com/bilingual-education-article

Crawford, J. (2000a). At war with diversity: US language policy in an age of anxiety. Clevedon, UK: Multilingual Matters.

Crawford, J. (2000b). Language politics in the United States: The paradox of bilingual education. In C. J. Ovando \& P. McLaren (Eds.), The politics of multiculturalism and bilingual education: Students and teachers caught in the crossfire (pp. 106-125). Boston: McGraw-Hill.

Delpit, L. (1995). Other's people's children: Cultural conflict in the classroom. New York: The New Press.

Demas, E., \& Saavedra, C. M. (2004). Reconceptualizing language advocacy: Weaving a postmodern mestizaje image of language. In K. Mutua \& B. B. Swadener (Eds.), Decolonizing research in cross-cultural contexts: Critical personal narratives (pp. 215-234). New York: SUNY Press.

Demont-Heinrich, C. (2007). Globalization, language, and the tongue-tied American: A textual analysis of American discourses on the global hegemony of English. Journal of Communication Inquiry, 31(2), 98-117.

Denzin, N. K. (2009). Critical pedagogy and democratic life or a radical democratic pedagogy. Cultural Studies/ Critical Methodologies, 9(3), 379-397.

Donegan, C. (1996). Debate over bilingualism. CQ Research, 6(3), 49-72.

Dressman, M. (2004). Deway and Bakhtin in dialogue: From Rosenblatt to a pedagogy of literature as social, aesthetic practice. In A. F. Ball \& S. W. Freedman (Eds.), Bakhtinian perspectives on language, literacy, and learning (pp. 34-52). Cambridge, UK: Cambridge University Press.

English-only movement. (n. d.). Retrieved from http://en.wikipedia.org/wiki/English-only movement

Evans, R. W. (2004). The social studies wars: What should we teach the children? New York: Teachers College Press.

Freire, P. (1998). Pedagogy of freedom: Ethics, democracy, and civic courage (P. Clarke, Trans.). Lanham, MD: Rowman \& Littlefield.

Freire, P. (2000). Pedagogy of the oppressed (30 th anniversary ed.). (M. B. Trans.). New York: Continuum.

Fulcher, G. \& Davidson, F. (2008). Tests in life and learning: A deathly dialogue. Educational Philosophy and Theory, 40(3), 407-417. 
Gann, R. R., Dean, B. P., \& Márquez, J. (2005). Beyond English hegemony: Language, migration and Appalachian schools. Changing English, 12(3), 431-441.

Gingrich, N. (1995). To renew America. New York: HarperCollins.

Halliday, M., \& Hasan, R. (1985). Language, context and text: Aspects of language in a social-semiotic perspective. Victoria, Australia: Deakin University Press.

Held, D., McGrew, A., Goldblatt, D., \& Perraton, J. (1999). Global transformations: Politics, economics and culture. Palo Alto, CA: Stanford University Press.

Johnson, M. (2004). A philosophy of second language acquisition. New Haven, CT: Yale University Press.

Katriel, T., \& Nesher, P. (1986). Gibush: The rhetoric of cohesion in Israeli school culture. Comparative Education Review, 30(2), 216-231.

Kliebard, H. M. (2004). The struggle for the American curriculum: 1893-1958 (3rd ed.). New York: RoutledgeFalmer.

Kouritzin, S. G. (2000). A mother's tongue. TESOL Quarterly, 34(2), 311-324.

Lincoln, Y., \& Guba, E. (1985). Naturalistic inquiry. Newbury Park, CA: Sage.

Lund, D. E., \& Nabavi, M. (2008). Duo-ethnographic conversation on social justice activism: Exploring issues of identity, racism, and activism with young people. Multicultural Education, 15(4), 27-32.

Madrid, A. (1990). Official English: A false policy issue. The Annals of the American Academy of Political and Social Science, 508, 62-65.

Moraes, M. (1996). Bilingual education: A dialogue with the Bakhtin Circle. New York: State University of New York Press.

NABE. (2008). What is bilingual education? [Data file]. Retrieved from http://www.nabe.org/education/index.html

National Center for Education Statistics. (2009). Language minority school-age children. Retrieved from

http://nces.ed.gov/programs/coe/2009/section1/indicator08.asp

National Education Association. (1966). The invisible minority: Report of the NEATuscon survey on the teaching of Spanish to the Spanish-speaking. Retrieved from http://www.eric.ed.gov/PDFS/ED017222.pdf

Norris, J. (2008). Duoethnography. In L. M. Given (Ed.), The Sage encyclopedia of qualitative research methods (pp. 233-236). Thousand Oaks, CA: Sage.

Nunan, D. (1991). Methods in second language classroom-oriented research. Studies in Second Language Acquisition, 13(2), 249-269.

Ong, A. (1999). Flexible citizenship: The cultural logics of transnationality. Durham, NC: Duke University Press. 
Panetta, L. E. (1999). Foreign language education: If "scandalous" in the 20th century, what will it be in the $21^{\text {st }}$ century? Retrieved from https://www.stanford.edu/dept/lc/language/about/conferencepapers/pan ettapaper.pdf

Reagan, T. G., \& Osborn, T. A. (2002). The foreign language educator in society: Toward a critical pedagogy. Mahwah, NJ: Lawrence Erlbaum.

Samimy, K. K. (2001). Comments on Sandra G. Kouritzin's "A mother's tongue": A reader reacts. TESOL Quarterly, 35(2), 323-325.

Saussure, F. (1959). Course in general linguistics. (W. Baskin, Trans.). New York: McGraw-Hill.

Saville-Troike, M. (2006). Introducing second language acquisition. Cambridge, UK: Cambridge University Press.

Schultz, F. (Ed.). (2001). Notable selections in education (3 $3^{\text {rd }}$ ed.). Guilford, CT: McGraw-Hill/Dushkin.

Simon, P. (1980). The tongue-tied American: Confronting the foreign language crisis. New York: Continuum.

Steinberg, S. (1992). Critical multiculturalism and democratic schooling: An interview with Peter McLaren and Joe Kincheloe. International Journal of Educational Reform, 1(4), 392-405.

Stritikus. (2002). Immigrant children and the politics of English-only: Views from the classroom. New York: LFB Scholarly Publishing.

Thomas, L. (1996). Language as power: A linguistic critique of US English. The Modern Language Journal, 80(ii), 129-140.

Turner-Vorbeck, T. (2006). Representations of family in curriculum: A poststructural analysis. In A. Segall, E. E. Heilman \& C. H. Cherryholmes (Eds.), Social studies: The next generation (pp. 153-169). New York: Peter Lang.

US ENGLISH. (2011). 31 states have enacted official English. Retrieved from http://www.us-english.org/

Wertsch, J. V. (2002). Voices of collective remembering. New York: Cambridge University Press.

Wong Fillmore, L. (1991). When learning a second language means losing the first. Early Childhood Research Quarterly, 6, 323-346.

Zimmerman, J. (2002). Whose America? Culture wars in the public schools. Cambridge, MA: Harvard University Press. 


\section{Appendix}

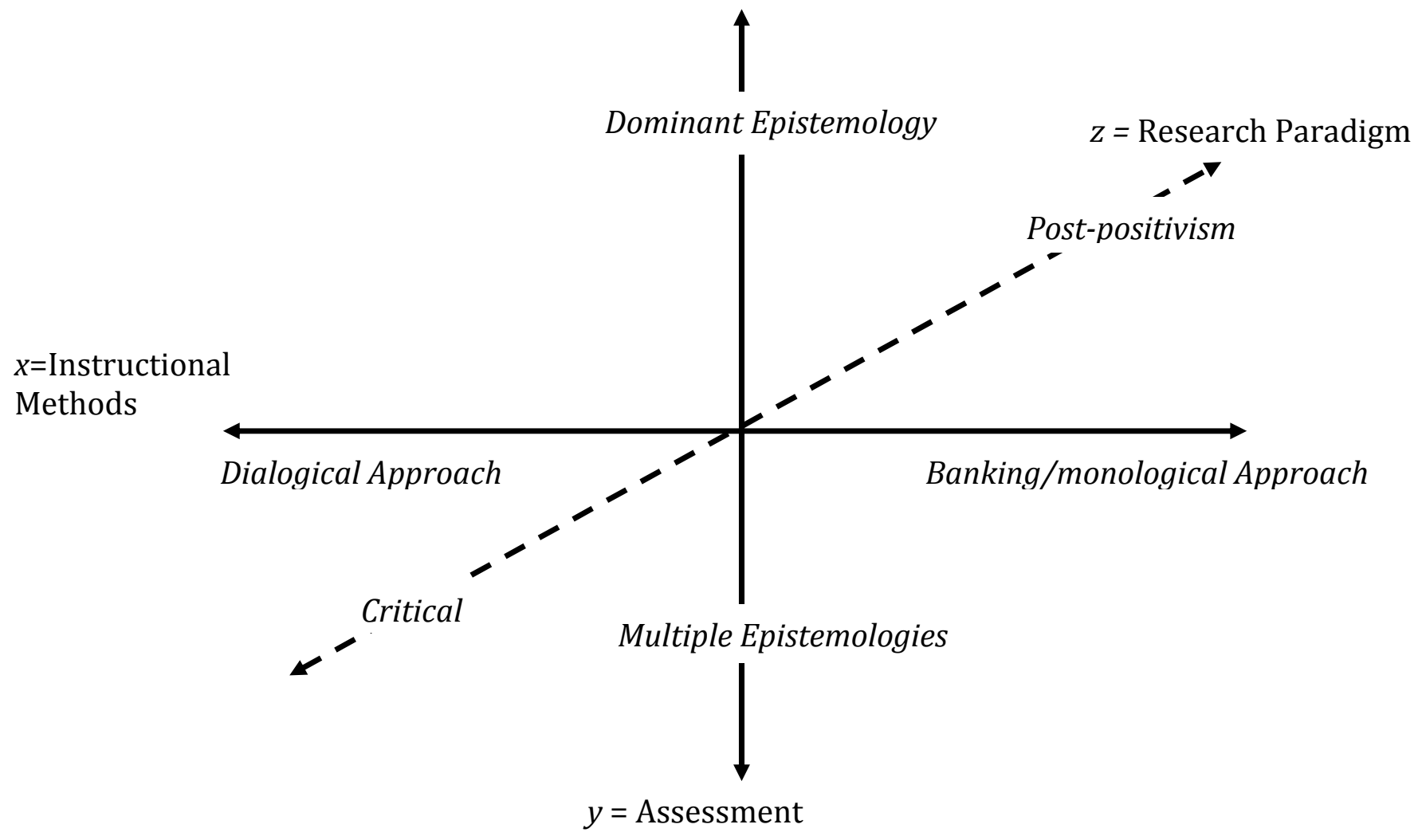

Figure 1. Three dimensions of language education 